Media Essay Review

\title{
Shedding Light on Shadow Education
}

\author{
MAGDA NUTSA KOBAKHIDZE
}

Aarakshan by Prakash Jha. Mumbai: Prakash Jha Productions, 2011. Hindi with English subtitles. 164 minutes. DVD. $\$ 9.95$.

3 Saat (3 Hours) by Can Candan. Istanbul: Studio Tiglon, 2008. Turkish with English and French subtitles. 118 minutes. \$34.52.

Private Tutoring in Cambodia by Privatization for Education Research Initiative. London: Cornucopia Productions, 2011. Khmer with English subtitles. 10 minutes. http://www.periglobal.org/role-state/video/video-private-tutoring-cambodia.

Rean Kua-Why Private Tutoring? by Tith Chandara from the Royal University of Phnom Penh. 2011. Khmer with English subtitles. 16 minutes. https://youtu .be/VKcuoKrJD0w.

This essay review examines four different movies that directly or indirectly refer to the theme of private tutoring or, as it is widely called, shadow education. The movies, directed in locations as diverse as India, Turkey, and Cambodia, are all made from a critical perspective. The directors demonstrate challenges in public education systems and reveal how the privatization of education affects the lives of students, parents, and teachers. The movies differ in genre: Aarakshan is a fiction drama, while the remaining three are documentaries. The documentaries vary in cinematographic techniques, composition, and quality: 3 Saat was made by a professional filmmaker, while Why Private Tutoring? was produced by a student.

\section{Aarakshan}

This movie is a 2011 Hindi narrative film based on the controversial policy of educational quotas for low-caste people. Directed by the Bollywood filmmaker Prakash Jha, who is mostly known for his sociopolitical films, the stars include award-winning actors Amitabh Machchan (as Prabhakar Anand), Saif Ali Khan (as Deepak Kumar) and Deepika Padukone (as Poorbi). Aarakshan addresses long-standing social issues, such as inequality, corruption, and nepotism, and portrays government officials who undermine public education

Comparative Education Review, vol. 59, no. 3.

(C) 2015 by the Comparative and International Education Society. All rights reserved. 0010-4086/2015/5903-0007\$10.00 
while establishing and encouraging educational business by opening profitmaking private tutoring centers. The title Aarakshan translates as "a reservation," referring to the quota-based affirmative action that allows low-caste students to gain entrance to higher education institutions and government jobs. This policy was controversial, especially among middle and upper middle classes in India. Director Prakash Jha is known for putting critical social justice issues into the mainstream Bollywood context, which makes such issues appealing for a popular audience. Aarakshan attracted much media and public attention both nationally and internationally.

Aarakshan is the story of Prabhakar Anand, an idealistic teacher and principal of the respected college STM, and his family, loyal students, and teachers. In the film, Anand offers free tutoring classes for students from all castes in the backyard of his house as an act of charity. The college standing committee opposes his approval of reservation, and he decides to resign from his post. The ruthless and newly appointed principal, Mithilesh Singh (portrayed by Manoj Baipayee), becomes Anand's enemy. Singh operates a private tutoring center in conjunction with the college. The story evolves as a battle between the Anand the idealistic teacher and Singh the opportunistic entrepreneur who dreams of creating an empire of profit-making tutoring centers. Anand is a man of principles who feels that education should be available for all regardless of social class affiliation and believes that "a person's intelligence and performance do not depend on one's background." Singh views education as a lucrative business and is ready to skip college classes to teach in the tutoring center. He sarcastically says to Anand, "In India's education system, there is no room for teachers like you."

The film slowly transitions from a love story between Anand's daughter Poorbi and Anand's student Deepak into a narrative of competition between the two tutoring centers, nonprofit and for profit. The first half of the film looks at Deepak's life and his failure to start a new job at the prestigious university because of his social background, while the second half depicts Anand's struggle to help students with examination preparation and to offer them equal educational opportunities through free tutoring.

This powerful Bollywood drama not only depicts the challenging lives of teachers and students and their frustration and conflict, rebellion, love, and friendship in the highly unequal environment but also carries an important message that education has been commercialized: in the words of one character, "There is no business bigger than education, paid service without a guarantee." Perhaps the director has tried to indicate that commercialization of education may exacerbate social inequalities in an already hierarchical society. Or perhaps he wants to suggest that with the excessive marketization of education, the future of India may be at risk.

Even with the lack of exploration into the nature of private tutoring, Aarakshan demonstrates a strong negative attitude toward fee-charging, com- 
mercial tutoring, while it favors nonprofit educational service. But how can an individual, charitable approach to inequality be effective system-wide? The director portrays Anand as a hero whose commitment to educational values should save India's education from commercialization. Anand strongly believes that something must be done, otherwise "private coaching ... will destroy everything!" However, his "solution" to educational inequality-offering free tutoring to students - is perhaps overly idealistic with regard to bringing social justice to India. The happy ending of Aarakshan, showing that moral values, professionalism, and loyalty win over corruption, selfishness, and dishonesty, seems naive when juxtaposed with the reality of India's highly stratified caste system.

Prakash Jha manages to show parents' and students' anxiety over the examination system but fails to explore their deep concerns about the system and its connection with the wider aims of education in India. The movie shows that families from all strata of the society in India are obsessed with private tutoring; a vivid impression is that every Indian student-low and high achievers alike-needs the service. But what drives such high demand? What is the role of mainstream education in preparing students for higher education? Questions that address the structural inequality remain unanswered. The film portrays private tutoring as the only option to succeed in the examination system. Public education has no true advocate in Aarakshan.

\section{Saat}

3 Saat (3 Hours) is a 2008 Turkish documentary that depicts the university student selection examination: each year over a million Turkish applicants take national test for three hours straight. 3 Saat explores the lives of six applicants-Çiğdem, Derya, Edin, Melis, Mert, and Yunus-before, during, and after the examination. Despite students' critical attitudes toward the examination system in Turkey, and despite their beliefs that one examination should not be the determinant of their future success, they still feel obliged to conform to the system because they see no escape.

The documentary focuses on the implication of examinations on the personal lives of the participants and follows these students and their families in high schools, private tutoring centers, and various social gatherings. Viewers witness aspirations, concerns, hopes, and disappointments. Turkey's highly competitive system is central to the lives of young people. Examination preparation puts them under enormous pressure and compromises their leisure time. As noted by one parent, "We steal ... their lives; we steal away their childhood. That's what the system requires; we cannot do anything."

The six university applicants come from diverse socioeconomic backgrounds and attend high schools in different neighborhoods of Istanbul. In spite of these differences, all families indicate that the educational ex- 
penditure causing the greatest financial burden is private tutoring. Attending a dersane, or a test preparation school, is perceived as necessary to secure success in the examinations. One parent remarks that "many families sacrifice a lot just to send their kid to test preparation school." And another echoes, "Now you cannot do without test preparation schools. Better accept it! Schools could be closed but the test schools, never!" The students reveal that they usually skip mainstream classes during the last two months of a graduating year and instead attend a dersane. Some even obtain false medical reports of sickness to justify their absence from schools.

3 Saat seems to suggest that the university examination selection system is a life-and-death issue for students and that Turkish society should reconsider its procedures, content, and mission. While the film depicts this system in an unfavorable light, the director tries to maintain objectivity by balancing opinions. For example, one school principal justifies the examination system by saying that "only this system can accommodate Turkey's needs," although this principal does not provide convincing arguments in the film. 3 Saat succeeds in allowing the viewer hear the voices of the students, parents, and school administrations but it omits policy makers' perspectives.

What makes 3 Saat an appealing documentary is not its visual perceptions or narrative coherence. Rather, it is its way of drawing emotional portraits of young people and its grasp of this complex social phenomenon. The film won awards from the Turkish Film Critics Association, the Ankara International Film Festival, and the International Istanbul Film Festival.

\section{The Pair of Cambodian Productions}

While 3 Saat is mainly focused on consumers' positions, the two short documentaries in this review, Private Tutoring in Cambodia (2011) and Why Private Tutoring? (2011), allow all main stakeholders of the education system to express their views. The former was produced by Cornucopia Productions for the Privatization in Education Research Initiative with the financial support from the Open Society Foundation. In contrast, the latter was a low-budget project directed by a Cambodian student Tith Chandara from the Royal University of Phnom Penh. Both documentaries problematize the phenomenon of private tutoring in a low-income country and link it with social inequalities, corruption, and unequal access to quality education.

The interviews with students, parents, teachers, school principals, an NGO representative and a teachers' union leader demonstrate that private tutoring plays a decisive role in Cambodian students' lives because they seem to require it to complete the curriculum and pass examinations. The major narrative in both films concentrates on the need for private tutoring and the difficulty for most people in both countries to afford it. This narrative is 
supported by parents' feelings of guilt for being unable to afford the service, as well as those of the students for asking their poor parents to pay for tutoring. These emotions are summarized by one student: "I do not have money and it is difficult. I do not feel equal" (Private Tutoring in Cambodia). The indispensable need for tutoring stems from the overloaded curriculum, low teacher salaries, and corruption in education. Teachers, who usually teach in both settings, acknowledge the importance of tutoring for students and see it as a normal practice. One teacher remarked, "Without private tutoring students are not able to get enough knowledge" (Why Private Tutoring?).

In the Cambodian documentaries, issues such as inequality, corruption, and inefficiency of the education system are portrayed in the light of teachers' low salaries in public schools. The teachers, policy makers, and school principals agree that teachers need second jobs to survive and that therefore no regulation of the tutoring market can be effective. While this aspect might be the central driver of shadow education in Cambodia, neither documentary goes into deeper issues, such as cultural acceptance, or other reasons for the normalization and institutionalization of shadow education. It is also disconcerting to hear a teachers' union leader state that the elimination of corruption in the government would allow policy makers to improve teachers' working conditions, which in turn would result in the teachers losing interest in providing tutoring, hence raising the quality of regular schooling. Unfortunately, this solution is not quite persuasive given the complex nature of private tutoring and multiplicity of factors determining success of education systems.

\section{Conclusion}

All four movies go beyond the educational context and show other aspects of social life in India, Turkey, and Cambodia. Specifically, the director of 3 Saat presents the national examination phenomenon in the wider context of social and economic life, demonstrating cultural values, gender roles, and different lifestyles of diverse social classes. For example, live TV reports on examination results, the anxiety of journalists behind the scenes, and media fixation on statistics of failure and success all reflect the news media's bias and its shallow nature. 3 Saat offers an alternative to the official narratives of mainstream media and sheds light on the human side of the examination process. Like 3 Saat, the directors of Why Private Tutoring? and Private Tutoring in Cambodia portray Cambodian society's struggle for economic survival and its quest for better educational opportunities. Perhaps for emphasis, the directors chose to depict only the most vulnerable families and excluded ones who could afford tutoring without pain.

While there has been increased focus on the phenomenon of private tutoring in international scholarly literature over the last two decades, much 
space remains for exploration. These narrative and documentary films illuminate the understanding of various aspects of the phenomenon and may be able to reach wider audiences than scholarly literature. Movies like Aarakshan, 3 Saat, and the two documentaries play an important educational role in popularizing major issues related to privatization of education and can be used as complementary teaching resources. Each movie refers to the shadow education phenomenon within the boundaries of genre, available resources, and diverse perspectives. While there is no deep exploration into the issue of private tutoring, its causes, or its relationships with public education, the directors manage to draw attention to major themes and demonstrate the magnitude of the shadow education in the lives of young people and in a society at large. The ubiquitous nature of the central topic makes the films relevant not only to the Indian, Turkish, and Cambodian contexts but also to many other locations. 